营床

高Na血症, 周期性四肢麻痺, その他多彩な 症状を呈した視床下部腫痬の 1 郜床例

\author{
虎の門病院神経科 \\ 山根 清美॰ 矢島一枝 塩沢 瞭一 安芸 基雄 \\ 虎の門病院内分泌科 \\ 紫芝 良昌 沢野 真二

\section{REPORT OF A CASE OF HYPOTHALAMIC TUMOR ASSOCIATED WITH HYPERNATREMIA AND PERIODIC PARALYSIS} \\ Kiyomi Yamane, M.D., Kazue Yajma, M.D., Ryoichi Shrozawa, M.D. \\ and Motoo Akr, M.D. \\ Department of Neurology, Toranomon Hospital, Tokyo \\ Yoshimasa Shishiba, M.D. and Shinji Sawano, M.D. \\ Department of Endocrinology, Toranomon Hospital, Tokyo
}

\begin{abstract}
摡要 中权性高 $\mathrm{Na}$ 血症については内外飞多数の報告がみられるが，それに関連して周期性四肢麻瘦 を生じたと考えられる例は希である。われわれは臨床的に視床下部腫演と診断された症例で正常脳开 水頭症，下垂体機能低下症，および，渴中权障害，A D H分泌障害に基つく高Na血症を呈し，それに 関連して周期性四肢麻㾇を生したと考点られる36才，男性の症例を経験した。ここに症例を報告する 之共に，麻瘏の発生機序について考案を試みた，当例ではchlorpropamideの投与，扣よび適当な水分 補給により血清Naを正常に保つことにより，四肢麻疩の発生をコントロール出来た．従来のspironolactone, acetazolamideなどの経験的薬物以外にもある種の周期性四肢麻㿉ではchlorpropamideが有効 な場合むあると考えられる。
\end{abstract}

\section{I.はじめに}

中枢性高Na血症については内外飞多数の報告 がみられ，それらの原因は視床下部に存在すると されている渴中权，A D H分泌中枢の異常にもと ぷく考兄られている。しかしながら中权性高Na 血症㳊関連し，四肢筋力低下の合併した症例は方 れわ机の知る限り希で，1971年Maddy'占らより 初めて注目され，この他飞は，外国では数例 ${ }^{2(3) 4) ，}$

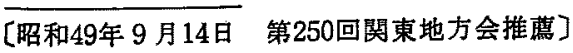

本邦で本多らによる 2 例》の報告をみるに過ぎな い.われわれは最近, 視床下部腫瘍之臨床的に診 断された症例で, 高Na血症, 周期性四肢麻痻を呈 し，かつ，高Na血症の消長と周期性四肢麻㽡の 間に何らかの因果関係が存在すると考觉られる症 例を経驗した。ここに症例を報告すると共に，麻 瘦の発生機序について考察を試みた。

\section{II. 症例}

患者：36才，男性。 
家族歴：特記事項なし.

既往歴：特記事項なし.

職業 : 会社員.

(1) 現病歴 :

生来, 健康で心身共にたくましく，会社であ業 務に積極的な社員として信頼もあつかつた。昭和 46年頃より動作が緩慢となり，元気なく，性格も おとなしくなり，物忘れがひどくなつた。それと 同時に，周期的に半日〜数日にわたる四肢筋の筋 力低下が括こり，起立不能となつたり，寝ていて もらとんを引張ることが出来ず，無理に動かすと 筋痛が括こることがあつたため，昭和47年 3 月 28 日，四肢筋力低下を主訴として東京慈恵会医科大 学入入院した，入院中，50\%glucose，および， regular insulinを 静注することにより四肢麻痺が 誘発され（表 1 )，麻痺発作時，血清Kは 2.1 $\mathrm{mEq} / l$ 飞下降乙，低 $\mathrm{K}$ 血症性周期性四肢麻疾々診 断された．その他の検查所見として，この頃より。 高 $\mathrm{Na}$ 血症 (血清 $\mathrm{Na} 158 \mathrm{mEq} / l$ ) 䯣液の細胞数，拉上 び，蛋白濃度の增加などの異常所見がみられてい るが，本人の事情により十分検索出来ないまま， 昭和 47 年 4 月中旬退院している．退院後も数回, 四肢筋力低下の発作を繰り返し，会社も休みがち であつた。昭和 48 年 2 月中旬, $38^{\circ} \mathrm{C}$ 以上の発熱の ため銀座菊地病院へ入院した.入院中,バンソウコ ウをパンと思つて食べる，実際に電話はしていな いのに会社の人と電話で話をしているつもりにな り，盛んに仕事の話をするなどの異常行動がみら れ，髄液中の蛋白濃度が $250 \mathrm{mg} / \mathrm{dl}$ と増加している 所見と合せて脳炎の疑いをすたれたが，3 日間で 解熱し，異常行動も消失したため，3月上旬退院 し, 自宅で静養していた。昭和48年 7 月, 左視力 の急速な低下を訴え，記銘力障害も著明となり，

表 1。誘発に上る四肢麻㾿発作

\begin{tabular}{|c|c|c|c|c|c|}
\hline & 前 & 20 分 & 90 分 & 120 分 & 24時間 \\
\hline $\mathrm{Na}(\mathrm{mEq} / l)$ & 158 & 150 & 150 & 150 & 161 \\
\hline$K \quad(m E q / l)$ & 3.4 & 3.4 & 2.1 & 2.1 & 3.5 \\
\hline
\end{tabular}

又， $38^{\circ} \mathrm{C}$ 以上の熱発をみたため，菊地病院に再入 院. 前回同様の髄液蛋白上昇がみられたため, 脳 腫㾤を疑われ，当院神経科入転院した。

\section{（2）当院第 1 回入院時の所見亡検查成樍}

a) 一般理学的所見

身長 $157 \mathrm{~cm}$ ，体重 $55 \mathrm{~kg}$, 脈拍 $96 / \mathrm{m}$, 整, 血圧 94/74mmg．一般身体的所見としては腋毛・陰毛 が粗である以外，特記すべき異常所見に乏しく， 扁桃腺肥大, 甲状腺腫大, リンパ節腫脹なく, 胸 腹部の理学的所見に異常を認めない。

b) 神経学的所見

意識は清明であるが動作，および，会話は緩慢 で見当識障害，作話傾向が認められ，記銘力低下 あり，眼底で乳頭が荅白である他には脳神経等に は異常をみない，歩行は不安定であるが四肢筋 力, 筋トーヌスは正常でとくに筋強剛は明らかで ない，深部反射は正常に保たれ左右差なく，病的 反射は認められない，小脳症状，および，知覚障 害子認められなかつた。

c）一般検查所見（表 2 )

総コレステロールが高値であること,トランス アミナーゼの獒度上昇，中程度の貧血以外，特別 の所見はみられなかつた。

d) 神経学的検查所見

䯣液は初圧 $100 \mathrm{mmH}_{2} \mathrm{O}$ と正常であるが，蛋白 は $180 \mathrm{mg} / \mathrm{dl}$ と著増, 細胞数は $100 / 3$ 個 (lymph 様72，不明 28$)$, 糖は49mg/dlであつた。脳血管写 (CA G)，では水頭症を示す所見のみ，気脳写 （P E G，図 1）では著明な側脳室の拡大がみら

\section{表 2 . 第 1 回入院庤一般検查所見}

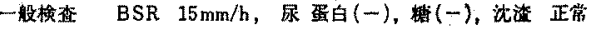
梴 虫卯 $(-)$, 潜血 (一)

末梢血 RBC $330 \times 10^{4}$, Hb $10.3 \mathrm{~g} / \mathrm{dl}$, plat $26.7 \times 10^{4}, \mathrm{WBC}$ 5600 , Stab 9\%, Seg. $43 \%$, Eos, $2 \%$, Bas. $1 \%$, Mon. $5 \%$, Ly. $40 \%$

血液生化学 T P $6.8 \mathrm{~g} / \mathrm{dl}, \mathrm{A} / \mathrm{G} 0.8$, TTT 2.9, ZST 5.5, Urea $-\mathrm{N} 15 \mathrm{mg} / \mathrm{dl}$, Creatinine $1.4 \mathrm{mg} / \mathrm{dl}, \mathrm{Na} 147-153 \mathrm{mEq} / \mathrm{l}$, $\mathrm{K} 3.8 \mathrm{mEq} / l$, Cl $107 \mathrm{mEq} / l$, T. Bil $0.6 \mathrm{mg} / \mathrm{dl}$, alk-P-ase 3.0 K-A單位, GOT 29單位, GPT 21 整位, LDH 206単位, CPK (Rosalky 変法) 95 㧘位, T. chol. $273 \mathrm{mg} / \mathrm{dl}$

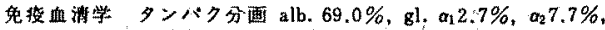
B 7.7\%, $\gamma 12.9 \%$, ASLO 125 Todd単位, CRP $( \pm)$, STS ( 3 法) (-)
} 


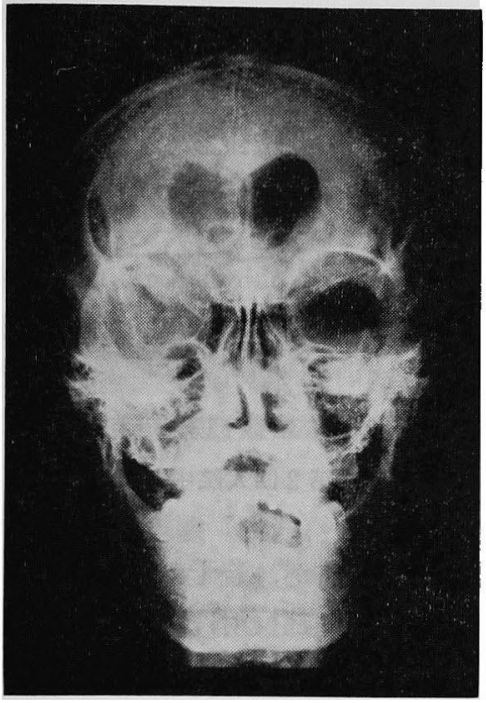

図 1。気脳写 (P E G) 著明な側脳室の拻大が み られる。

れた。

RISA-cysternographyでは注入後，6時間で側 脳室内へのR I S A の逆流, 貯留がみられた. 更 に空気脳室撮影（PV C, 図 2 ）で第 3 脳室前半 部の充盈欠損像が得られ，脳シンチグラムでも同 部にhot depositが認められた．脳波では基本波は 7-8cps波でびまん性に $\theta$ 波が 混在し，汎発性 徐波化，不規則化を示した。眼科的検査では

$$
\begin{aligned}
& \text { v.d. }=0.7\left(1.2 \times \mathrm{Cyl}-1.0 \mathrm{D} 90^{\circ}\right) \\
& \text { v.s. }=0.02 \text { (n.c.) }
\end{aligned}
$$

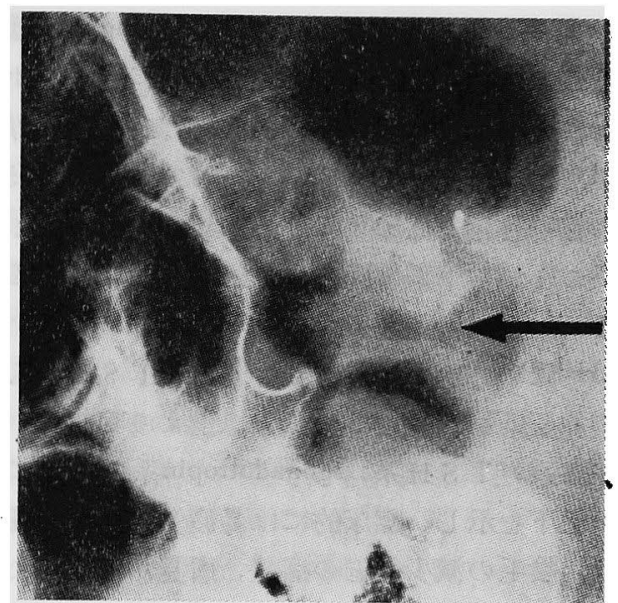

図2. 空気脳室撮影 (PVG) 矢印は第 3 脳室前 半の充盈欠損を示す。

と左眼視力の著しい低下，又，図３に示すように 左眼耳側の部分的視野欠損が認められた。眼底は 両眼共, 乳頭の耳側が蒼白であるが, うつ血乳頭, 扣よび，動脈硬化などの所見は認められなかつた (これらの所見と前述の臨床症状，および 後述の 下垂体機能低下症から本例は 視床下部腫瘍を 有 し，その結果と考えられる正常脳圧水頭症（以下 N P H）を併発しているるのと診断された).

e) 内分泌学的検査所見

内分泌学的検査においては，成長ホルモンは， インスリン，アルギニン負荷に対して反応せず， 又, 副腎皮質ホルモンについては血浆コーチゾー ルは検出下限值 $(1.0 \mu \mathrm{g} / \mathrm{dl})$ 以下で日内変動な

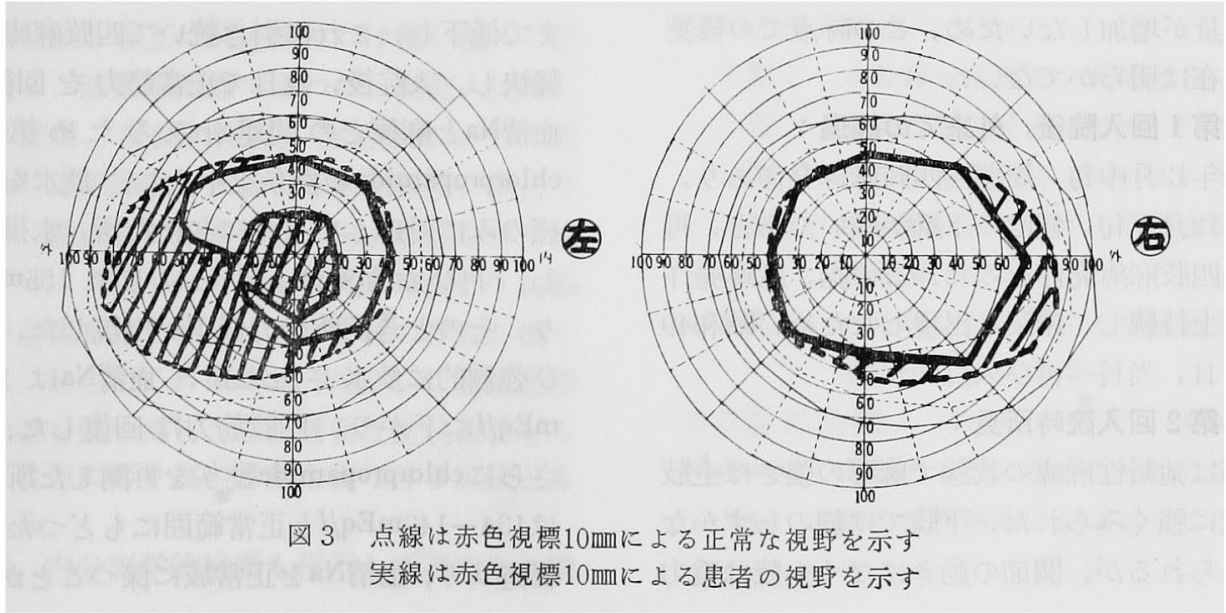


く，17-KS $1.4 \mathrm{mg} / \mathrm{d}, 17-\mathrm{OHCS} 1.2 \mathrm{mg} / \mathrm{d}$ と 低值 でAC T H分泌の低下が想像された。甲状腺ホル モンについてはtotal thyroxine $1.4-2.3 \mu \mathrm{g} / \mathrm{dl}$, $\mathrm{RT}_{8} \mathrm{U} 25-31 \%$ と共に低下しており， T R H 500 $\mu \mathrm{g}$ の静脈注射によつても T S H の增加をみとめ ないことから下垂体性，または，視床下部性の T S Hの欠損が考光られた．gonadotropinについて はLH-RH $100 \mu \mathrm{g}$ 皮下注射飞対してF S Hも L H も增加反応を示さなかつた（以上より G H系，A C TH系, T S H系, gonadotropin系のすべてが 機能低下を示し, 臨床的には易疲労感, 低血圧, 腋毛，陰毛の減少などの症状，所見がみられたこ とから下垂体機能低下症と診断された).

(3) 第 1 回入院中の経過 :

上述の如く，まず，N P H に対乙当院脳外科に おいてて, Onmaya's reservoir setting, V-P shuntを 施行した所, 精神症状, 意識状態は著明に軽快し た。視床下部腫瘍に対しては ${ }^{60} \mathrm{Co}$ 照射 (5100rads) を行ない，下垂体機能低下症に対してはhydrocortisone $20 \mathrm{mg} / \mathrm{d}$, l-thyroxine (Thyradin S) $100 \mathrm{r} / \mathrm{d}$, testosterone-propionate (Enarmon-Depot) 200 $\mathrm{mg} /$ monthによるホルモン補充療法を行なつた. これ らの治療により，全身状態は著明に回復し，職場 復帰出来る程となり昭和48年11月退院した。なお， 視床下部腫瘍では脳下垂体前葉, 後葉不全がしば しばあり, 前葉不全の際, 後葉不全が maskされ ることがあるが，本例では前葉ホルモン補充によ つても尿量が増加しないため，この時点での後葉 不全の存在は明らかでない.

（4）第 1 回入院後, 外来での経過 :

昭和48年12月中旬, 周期性四肢麻瘏発作あり, 昭和48年12月下旬, 軽度の下痢が続いたあと, 再 び周期性四肢麻痺発作をみた。この際，麻痺発作 が 3 日以上持続し，尿閉も出現したため，昭和 49 年 1 月 5 日, 当科へ再び入院した。

(5) 第 2 回入院時所見 :

四肢筋は弛緩性麻痺の状態で麻痷の強さは上肢 より下肢に強くみられた，下肢では筋のわずかな 収縮はみられるが，関節の動きはなく上肢は重力

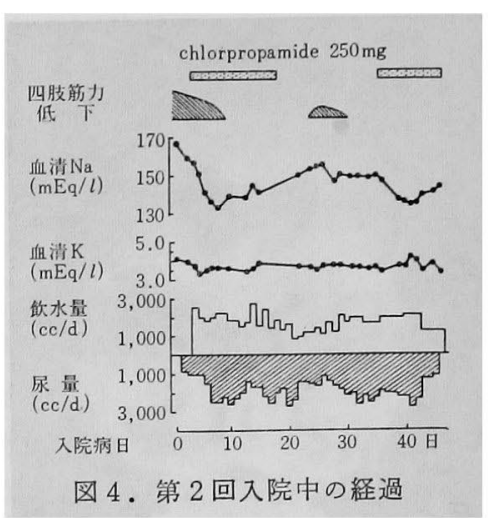

に抗して運動出来るが, 若干の抵抗を与えると運 動出来なかつた。深部反射は上下肢共に軽度の低 下を示した．病的反射, 知覚障害共に認められな かつた，四肢麻疩と共に膀胱直腸障害がみられ， 自発的に排尿出来ず，導尿を行なつた所，1200cc の尿貯留がみられた。

（6）第 2 回入院中の経過（図 4）:

入院時, 四肢麻痷発作中において血清Kは 4.1 $\mathrm{mEq} /$ と正常を示したにもかかわらず，血清Naは $167 \mathrm{mEq} / l$ と高值を示した。低 $\mathrm{K}$ 血症による周期 性四肢麻痺発作中, 回復直前にこの様な所見を示 すこともあり得るとは考えられるが正常 $\mathrm{K}$ 濃度を 示したことより，高Na血症の治療を行なえば四肢 麻疸も軽快し得るかも知れないと考えて, 強制的 水分補給, および, chlorpropamideの投与を行なつ た。 その結果，血清Naは第 7 病日には $133 \mathrm{mEq} / l$ まで低下し，これに引き続いて四肢麻疩も徐々に 軽快し, 入院後, 数日で正常筋力を回復した. 血清Na と麻㾝との関連をみる。め第18病日に chlorpropamideの投与を中止し，领水を本人の渴 感のみに対応して自由に与えた所，水摄取は減少 し，再び血清Naは上昇しはじめ $155 \mathrm{mEq} /$ とな り，そのとき四肢筋力低下が出現した．そこで再 び強制的に领水させた所，血清Naは 147- 150 $\mathrm{mEq} /$ lに下がり，四肢筋力は回復した。 そこで さらにchlorpropamide投与を再開した所，血清Na は134-143mEq/lと正常範囲にもどつた．以上の 経過より，血清Naを正常域に保つことが重要であ 
表 3.12時間水制限テスト（第 2 回目入院中に実施）

\begin{tabular}{|c|c|c|}
\hline & $\begin{array}{l}\text { 水制限 } \\
\text { 始娃洔 }\end{array}$ & $\begin{array}{l}\text { 永制眼 } \\
\text { 時了时 }\end{array}$ \\
\hline 血清没透厓 $(\mathrm{m} 0 \mathrm{sm} / \mathrm{kg})$ & 314 & 324 \\
\hline 尿澓透压 $(\mathrm{mOsm} / \mathrm{kg})$ & 423 & 672 \\
\hline 血溥 $\mathrm{Na}(\mathrm{mE} \mathbf{q} / l)$ & 151 & 153 \\
\hline
\end{tabular}

ると考え，chlorpropamide投与を行ない，1 日2000 cc程度の飲水が必要であることを患者に指導し， 退院させた，退院後， 1 年間, 外来で経過観察を 行なつているが，四肢麻㽻の発作なく順調に経過 している.

（7）水制限試験（表 3）:

さて, 血清 $\mathrm{Na}$ のこの様な増加は口渴中权, おょ び，それに関連したADH分泌中权の異常が生じ てきたことによると考充られる。この点を明らか にするために水制限試験を行なつた。12時間の水 制限を行ない,その前後の尿浸透王，血清浸透圧， 血清電解質を調べた。血清浸透圧は $314 \mathrm{mOsm} / \mathrm{kg}$ と水制限前からすでに高い值を示し，水制限によ り $324 \mathrm{mOsm} / \mathrm{kg}$ で著しく上昇した。それにも かかわらず尿浸透圧は $423 \mathrm{mOsm} / \mathrm{kg}$ より 672 $\mathrm{mOsm} / \mathrm{kg}$ をでしか上昇せず，尿濃縮力は低下し ている.この結果から渴中枢の障害により，水分 揁取が障害されているが，A D H分泌のre-setting が起こつている可能性が考えられる．

\section{III. 考案}

（1）視床下部腫瘍および N P Hの猃断につい $\tau$

本例は当初, 相互に関連性のつけ難い種々の症 状が出没し，診断が困難であつた，当院入院時，

1）性格変化, 記銘力障害, 作話傾向などの症 状, 錐体外路采障害を示唆する動作緩慢, 歩行不 安定，2）䯑迹液圧が正常，3）内水頭症を示す検 查所見，4）RISA-cysternographyで髄液 の 側脳 室内への逆流を示す所見からN P H 存在が強く 疑われた。そこでV-P shuntを作製 して䯣液循環 動態の改善を計つたところ，著明な症状改善をみ た。これは逆にN P Hの診断を裏づける成績とも 考えられる。

この間, 内分泌学的検索も平行して進められ精
神症状の消失に伴つて神経学的所見もさらに明ら かになつて，1）沉下垂体機能低下症の存在，渴 中权の破壊を示唆する所見，2）視野欠損の存 在，3）䯣液蛋白の増量，4）脳シンチグラムで 陽珄所見, 5) 気脳写, 空気脳室撮影の結果, 第 3 脳室前半部の充盈欠損を証明されたことから視床 下部腫瘍と診断された。届瘍の組織学的検索は 行なわれていないか゚, ectopic pinealomaあるいは astrocytomaが疑われている，第3脳室前半に占 居性massを有するN P Hは，まさにAdams原著の 第 3 例と一致する所である ${ }^{6)}$.

(2) 高Na血症の成因について

本例は高浸透圧，高Na血症時においてさえも尿 量は正常で口渴感はほとんど欠如していたことよ り，まず，口渴中枢の異常が高Na血症の原因とな つたと考えられる. 次に A D H分泌機能について は水制限により血清浸透圧が十分，上昇したkる かかわらず，尿浸透圧上昇の程度は少なかつた。 尿浸透压は血清漫透圧を越えているのでA D Hが 分泌されていることは示されるが，上昇の程度の 少ないことよりADHの分泌不全，或はosmolar resetが考えられる．口渴中权とADH分泌中枢は 視床下部で近い位置, 或は一部重複した位置にあ ると実験的に推察されて打り》 10)，本例では視 床下部腫鈞により，これらの中枢が同時に，不完 全ではあるが障害され，高Na血症をひき和こす 原因になつたと考えられる，Mahoney ${ }^{11}$ は中枢性 高Na血症の成因につき，

1 型：ADH分泌次, 渴感正常

2型：A D H分泌正常, 渴感低下, または欠如

3 型：A D H分泌久如, 渴感低下, または欠如

4 型：A D H分泌に対する刺激闘值え進，渴 感正常

5 型：A D H分泌に対する刺激閾值九進，渴 感低下，または欠如

の5型に分類している。本例の高Na血症は， Mahoneyの分類の 5 型に属するものと思われる。

（3）本例の四肢麻痻，拈よび，その成因つ いて 
表 4. 血洓 $\mathrm{Na}, \mathrm{K}$ と麻疩発作の関係

\begin{tabular}{|c|c|c|c|c|}
\hline 日 & $\mathrm{Na}(\mathrm{mEq} / l)$ & $\mathrm{K}(\mathrm{mEq} / l)$ & 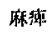 & 治㻢 \\
\hline S.48.12.17. & 155 & 4.0 & $(+)$ & $(-)$ \\
\hline S.49.1. 5 . & 167 & 4.1 & $(+)$ & $(-)$ \\
\hline S.49.1.7. & 159 & 3.9 & $(+)$ & $(-)$ \\
\hline S.49.1.8. & 157 & 3.7 & $(+)$ & $(-)$ \\
\hline S.49.1.29. & 154 & 3.5 & $(+)$ & $(-)$ \\
\hline S.49.1. 30 & 155 & 3.7 & $(+)$ & $(-)$ \\
\hline S.49.4. 3 & 160 & 4.0 & $(-)$ & $(-)$ \\
\hline \multicolumn{5}{|c|}{ chlorpropamide 治港吸 } \\
\hline S. 49.1 .12 . & 133 & 3.0 & $(-)$ & $(+)$ \\
\hline S. 49.1 .17 . & 138 & 3.4 & $(-)$ & $(+)$ \\
\hline S.49.1.18. & 144 & 3.5 & $(-)$ & $(+)$ \\
\hline S. 49.2 .12 . & 136 & 3.7 & $(-)$ & $(+)$ \\
\hline S.49.2.13. & 135 & 3.6 & $(-)$ & $(+)$ \\
\hline
\end{tabular}

まず，本例の四肢麻㽻にか九する臨床像につい ては，1）間歇的に四肢筋力低下の 発作を起こ し，弛楥性四肢麻㽻の形をとつた。2）発作時以 外には正常筋力を示した．3）知覚障害は発作時 にも伴わない，4）発作の強いときには膀脂直腸 障害を伴つたことなどがあげられる．周期性四肢 麻瘏は一つの症候群であつて単一の疾患ではない が，以上の症候より本例の四肢麻痺が一般に周期 性四肢麻痺と呼ばれているるのに一致する事は明 らかである，次に本例の周期性四肢麻痺にみられ た特徴として，1） 発作のある時は必ず，血清 $\mathrm{Na}$ が高い（表4），2）血清Kは必ずしも低くない （表 4).3）誘発試験としてglucose とinsulinを静 注すると，麻痺は招来され，血清 Kは低值となり 血清Naは一部上昇している(表 1).4） chlorpropamideが奏功した（血清Na濃度を減少させるこ とによつてか，或は，直接的に作用したかどらか は不明であるが).5）周期性四肢麻㿁の家族歴 はない。などがあげられる，血清Kが発作中，必 ずしも低下していないことは，本例に括いては， 一つの特徵ではあるが，低K血症を伴う周期性四 肢麻痷に执いても発作の初期をのぞいて血清Kは 必ずしも低くない場合があり，これのみで，本例 が低 K血症性周期性四肢麻瘏に属さないとするこ とは困難である。しかし，同時化正K血症性周期 性四肢麻痺を考慮して和かねばならない，後者 の場合, Poskanzer 5 ${ }^{12)}$ ，鎮目，紫芝 ${ }^{182}$ の症例 においても $\mathrm{KCl}$ で誘発される，つまり potassium- inducedである性質が明らかなこと，末梢性知覚 鈍麻を伴うこと，また，glucose，および，insulin の静注では麻痺は誘発されないことなどが報告さ れており，本例の特徵はこの分類にあてはまらな いと考えられる。次にglucose，特よびinsulinkよ り麻痺が誘発されたといら点より考学ると，家族 性(散発性)低K血症性周期性四肢麻痺，或いは， 甲状腺中毒症性周期性四肢麻痺を考慮する必要が ある. 本例が甲状腺中毒症性周期性四肢麻疾でな いことは甲状腺腫がないこと，血清 $\mathrm{T}_{4}, \mathrm{RT}_{8} \mathrm{U}$ が むしろ低下していることから明らかであろう。

さて，われわれの症例が散発性低 $\mathrm{K}$ 血症性周期 性四肢麻㿇であるかどらかについてでするが，わ れわれの経験では散発性低 $\mathrm{K}$ 血症性周期性四肢麻 痺では初発年令は10才台，20才台に多く，30才台 で初発するのは比較的少ないこと，また，自然発 作中，著明な低K血症の発見される確率が高いこ となどの特徵を有することる考えると，本例で は，麻瘏時に低K血症を見逃した可能性は否定は 出来ないが，少なくともこの分類の典型的症例と は考光にくいのである。鑑別すべき周期性四肢麻 痺の成因は以上の様なものとすると，本例の周期 性四肢麻痺の成因を解釈する上で最む重要なもの は，本例で麻痺発作時に必ず，血清Naの上昇を みることにあると思われる。

ここで高Na血症の際，水分の分布がどの様な 形であつたかを考慮しておきたい，本例では麻 痷時に高 $\mathrm{Na}$ 血症を示した際, 同時に高Cl血症も存 在した。他のデーターではTP $6.6 \mathrm{mg} / \mathrm{dl}$ ， urea $\mathrm{N}$

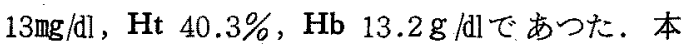
例で正常血清Na濃度を示している際のHb 10.3$12.4 \mathrm{~g} / \mathrm{dl}, \mathrm{Ht} 25.0-35.7 \%$ で, 高Na血症の際の それらよりも低い值であり，従つて高Na血症の 存在する際はhemoconcentrationが存在していた と推察される。本例では口渴中枢，A D H分泌中 枢の異常のため, 細胞外液中の主として水分が不 足し, hypertonic dehydrationの状態となり，同時 に，hemoconcentrationの状態も存在したである 丂. 
従来, 散発性低 $\mathrm{K}$ 血症性周期性四肢麻㽻におい ても発作期間中，血清Na显をみることが多 く, 繰り返し述べる如く，本例の高Na血症と四 肢麻疩との関連で周期性四肢麻瘁の結果生したた水 分のre-distributionに伴う，高 $\mathrm{Na}$ 血症である可能 性る完全には否定することは出来ない，偶然，散 発性低 $\mathrm{K}$ 血症性周期性四肢麻痺と視床下部腫瘍之 が同一人に同一時期に発生したといら考方方も不 可能ではない，しかし，逆に血清Naの上昇が周 期性四肢麻瘦の誘因を作るかどうかを考光てみる こともまた，重要なはずである。

周期性四肢麻痺はmembrane potential, Eの減少

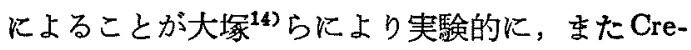
tzfeldt ${ }^{15)}$, 里吉 ${ }^{16)} ら に よ り$ 臨床的に確かめられ ている．麻痷の起こり易い状態はHodgkin and $\mathrm{Katz}^{172}$ の式,

$$
E=\frac{R T}{F} \operatorname{In} \frac{P_{K}[K]_{i}+P_{\mathrm{Na}}[\mathrm{Na}]_{i}+P_{\mathrm{Cl}}[\mathrm{Cl}]_{0}}{P_{K}[\mathrm{~K}]_{0}+P_{\mathrm{Na}}[\mathrm{Na}]_{0}+\mathrm{P}_{\mathrm{Cl}}[\mathrm{Cl}]_{\mathrm{i}}}
$$

（たら゙し， $\mathrm{E}$ : 静止膜電位， $\mathrm{R}$ : ガス定数,

$$
\text { F：Faraday定数, } \mathrm{T} \text { ：絶対温度 }
$$

$[\mathrm{K}] \mathrm{o}$ ：細胞外 $\mathrm{K}$ 濃度 [K]i：細胞内 $\mathrm{K}$ 濃度 [Na]o: 細胞外Na濃度 [Na〕i: 細胞内 $\mathrm{Na}$ 濃度 〔Cl]o: 細胞外Cl濃度 [Cl]i：細胞内Cl濃度 $\mathrm{P}_{\mathrm{K}}, \mathrm{P}_{\mathrm{Na}}, \mathrm{P}_{\mathrm{Cl}}$ ： 各イオンの透過定数

この際, $\mathrm{P}_{\mathrm{Cl}}$ の $\mathrm{P}_{\mathrm{Na}}$ に比し, 著しく小さいのでCl にかんする項は無視出来るから

$$
\mathrm{E}=\frac{\mathrm{R} \mathrm{T}}{\mathrm{F}} \operatorname{In} \frac{\mathrm{P}_{\mathrm{K}}[\mathrm{K}]_{\mathrm{i}}+\mathrm{P}_{\mathrm{Na}}[\mathrm{Na}]_{1}}{\mathrm{P}_{\mathrm{K}}[\mathrm{K}]_{0}+\mathrm{P}_{\mathrm{Na}}[\mathrm{Na}]_{0}}
$$

と単純化することが出来る) において $\mathrm{P}_{\mathrm{Na}}$ が増加 しているか，或いは，P莸低下しているかである が，本例では $\mathrm{P}_{\mathrm{Na}}$ が増加していたために[Na]。のわ ずかな上昇でる麻㽻の引き金をひいたのではない かと推察される。 さらにchlorpropamideの治療に より $[\mathrm{Na}]_{\circ}$ が低くなつた時期では麻痺が起こらな いことるこの考えでよく説明されうる。 insulinの 投与，または，glucose投与による内因性insulinの 增加は, $\mathrm{P}_{\mathrm{Na}}$ 增加，〔K〕。の減少による $\mathrm{P}_{\mathrm{K}}$ の減少と いら機序で麻痺を起こしらることは大塚ら ${ }^{14}$ によ り実験的に説明されていることである。次に麻疩 発作中に血清Naがさらに上昇する理由について は，A D H異常の他に里吉ら ${ }^{183}$ が主張する如く， 麻瘒発作に伴ら水分のre-distributionという因子を 考慮しなくてはならないと考える，何れにせよ Hodgkin and Katz ${ }^{17)}$ の式で明らかな様に，本症例 では血清Naの上昇が 麻痺の一つの準備状態とな り得たと考光られる。本例に括いてchlorpropamide投与により血清Naが正常化されるとともに麻 㽻の発生をみなくなつた事実むこの考えを裏つけけ るものであろう、いずれにせよ,この様な症例にお いてはKCl, spironolactone, acetazolamideなど従 来, この疾患に慣用されている薬剤よりもchlorpropamideが奏功することは今後の症例の治療の上 に重要な参考となる事項であるう。

\section{IV. まとめ}

われわれは視床下部腫瘍之臨床的に診断された 症例で，正常脳圧水頭症，下垂体機能低下症纱よ び，A D H分泌異常，渴中枢障害に基づく高 $\mathrm{Na}$ 血 症を呈しそれに関連して周期性四肢麻痷が生じた 症例を経験し，その成因につき，考察を試みた。

謝辞 本症例の資料の提供をして頂いた東京憼恵会 医科大学阿部内科, および銀來菊地病院の諸先生方に厚 く御礼申乙上げます。

\section{文献}

1) Maddy, J.A. and Wirternitz, W.W.: Hypothalamic syndrome with hypernatremia and muscular paralysis, Amer. J. Med., 51: 394, 1971.-2) Kastin, A.J., Lipsett, M.B., Ommaya, A.K. and Moser, J.M.: Asymptomatic hypernatremia, Amer. J. Med., 38: 306, 1965.-3) Segar, W.E.: Chronic hyperosmolality, Amer. J. Dis. Child., 112: 318, 1966.-4) Pleasure, D. and Goldberg, M.: Neurogenic hypernatremia, Arch. Neurol. (Chicago), 15: 78, 1966.一5) 本多虔夫, 斉藤佳雄, 岡田年弘, 平井秀幸, 塩原隆造: 周期性四肢麻㾇学 主街とした高ナトリウム血症を伴ら視床下部腫瘍 の 2 剖检例，蹦床神経, $14: 462,1974$. 一6) Adams, R.D., Fisher, G.M., Haskin, S., Ojemann, R.G. and Sweet, W.H.: Symptomatic occult hydrocephalus with "normal" cerebrospinalfuid pressure, New. Eng. J. Med., 273: 117, 1965. -7) Goldberg, M.: Hyponatremia and the inappropriate secretion of antidiuretic hormone, editorial, Amer. J. Med. 35: 293, 1963. -8) Montemurro, D.G. and Stevenson, J.A.F.: The localization of hypothalamic structures in the rat influencing water consumption, Yale J. Biol. Med.,28: 396, 1955 
1956.-9) Andersson, B. and McCann, S.M.: Drinking, antidiuresis and milk ejection from electrical stimulation within the hypothalamus of the goat, Acta Physiol. Scand., 35: 312, 1955. -10) Andersson, B. and McCann, S.M.: The effect of hypothalamic lesions on the water intake of the dog, Acta Physiol. Scand., 35:312, 1955.

11) Mahoney, J.H. and Goodman, A.D.: Hypernatremia due tohy podipsia and elevated threshold for vasopressin release, New Eng. J. Med., 279: 1191, 1968.-12) Poskanzer, D.C. and Kerr, D.N.S.: A third type of periodic paralysis, with normokalemia and favorable response to sodium chloride, Amer. J. Med., 31: 328, 1961.-13) 中尾 砶久，鎮目和夫，紫芝良昌，佐久間真㴻，矢野雄三： Potassium induced, sodium responsive periodic para- lysis, 日内会誌, $53: 1185,1964 .-14)$ Otsuka, M. and Ohtsuki, I.: Mechanism of muscular paralysis by insulin with special reference to periodic paralysis, Amer. J. Physiol., 219: 1178,1970.

15) Creutzfeldt, O.D., Abbott, B.C., Fowler, W. M. and Pearson, C.M.: Muscle membrane potentials in episodic adynamia, Electroenchph. clin. Neurophysiol., 15: 508, 1963. -16) 里吉営二郎, 村上度郎，岡綺隆，竹田昌俥：2，3の筇疾患飞打 ける筋静止膜䉓位, 監休脳波, 5:136, 1963, -17) Hodgkin, A.L. and Katz, B.: The effect of sodium ions on the electrical activity of the giant axon of the squid, J. Physiol,, 108: 33, 1949. 18）里吉営二郎，村上㿑郎，古和久幸，木下真男 : 周期性四肢麻痺発現の機序に関士る新しい見解, 臨 内小, $16: 1179,1961$. 